\title{
Preliminaries to European Integration in the Transylvanian Area (Case Study on Unity and Diversity)
}

\author{
Ioan-Aurel POP
}

\section{What is Transylvania?}

Through some of its most important characteristics, Transylvania may be considered (and it sometimes was) a smaller Europe. Although, due to its Latin resonance, the name Transylvania (initially Ultrasilvana) may seem rather exotic and old, it actually does not date back to the antiquity, but to the threshold of the first and the second millennia of the Christian era, meaning "over the forest" or "beyond the forest". ${ }^{1}$ Today, the name is given, in the common language, to a wide area (of almost 100,000 square kilometres), situated to the north of the Southern Carpathians (the Transylvanian Alps) and west of the Eastern Carpathians, an integrative part of Romania, accounting for approximately $40 \%$ of the surface area of the country. The current population of Transylvania is approximately 7 million (more than a third of Romania's population), of which over $75 \%$ are Romanians, approximately $17 \%$ are Hungarians, and the rest are Roma (Gypsies), Slavs, Germans etc.

\section{The image of Transylvania - the smaller Europe}

In the $21^{\text {st }}$ century, this Transylvania (Erdély in Hungarian, Siebenbürgen in German) still bears the marks of a troubled past considerably different from anything experienced by other regions of Europe. At first glance, quite striking in both rural and urban areas is the close proximity of various churches, from the Byzantine and Neo-Byzantine cupolas of the Orthodox churches to the Gothic towers piercing the urban skyline, from the round arches of the Romanesque churches to the Baroque façades of other places of worship. In some regions, on an area measuring barely a few hundred square meters, one can see Orthodox and Greek-Catholic churches standing beside Roman-Catholic, Calvinist, Lutheran or Unitarian ones, all not very far from a synagogue. For instance, in the city of Cluj-Napoca (Clus, Kolozsvár, Klausenburg, Claudiopolis), the traditional capital of the province, we find today five Christian prelates of episcopal rank or higher (an Orthodox metropolitan bishop, a Greek-Catholic bishop, a Calvinist bishop, a Lutheran bishop and a Unitarian one), as well as an episcopal vicar (RomanCatholic), while the local Babeş-Bolyai University (with approximately 42,000 undergraduate, postgraduate and doctoral students and faculty members) has four

1 See I.-A. Pop, Romanians and Hungarians from the 9th to the 14th Century. The Genesis of the Transylvanian Medieval State, Cluj-Napoca, 1996, pp. 5-11, 140-151. 
faculties of theology (two having Romanian as the language of instruction and two where the teaching is done in Hungarian), according to the main historical denominations of the country. Transylvania is the only place in Europe to have such a complex cultural and religious structure, the only place where Romanesque and Gothic monuments stand beside Byzantine, Renaissance, Baroque or even Secession (Modern Style, Jugendstil, Art Nouveau) ones. East of the Transylvanian border, the Romanesque style is completely absent and the Gothic blends into the Moldavian style devised in an old Romanian environment that spiritually vacillated between Constantinople (the New Rome) and Moscow (the Third Rome), following the path of "Byzantium after Byzantium" (to quote Nicolae Iorga) or of the Byzantine Commonwealth, as Dmitri Obolenski put it. ${ }^{2}$

During the Middle Ages, Transylvania brought together the models of Eastern (Orthodox) and Western (Catholic) spiritual life, while the modern era further diversified the landscape by adding Protestant, Hebrew, Neo-Protestant etc. components. For longer or shorter periods of time, all of these models were endangered, competed with and fought one another, threatened one another's existence, but eventually coexisted and exercised mutual influences, shaping this unique Transylvanian world that, for this very reason, came to be known in some circles as a world of tolerance. According to the reality, as well as to each one's interpretation, this Transylvanian "tolerance" meant acceptance and rejection, welcoming and exclusion, equality and segregation, giving its society a sui generis form and functioning.

Consequently, Transylvania's character of a smaller Europe refers to its habitat, to the aspect of the dwellings and of the architectonic styles, to its basic ethnical and linguistic groups (Romanic, German and Slavic, plus Finno-Ugric), to its main religions and cults (Orthodox, Catholic, Hebrew, Protestant and NeoProtestant etc.). All these elements personalise the continent, as Europe (along with Transylvania) reunites all these characteristics under its cupola.

\section{Transylvania - between medieval tradition and modernity}

Transylvania was also a nursery for European ideas concerning, at the same time, habitation and cohabitation, unity and segregation, integration and disintegration, acceptance and exclusion. This heritage and vocation come from ancient times, when the seal of Rome was affixed - two millennia ago - at the Carpathians and at the Danube. At that time, the Thraco-Dacian world was integrated into the tricontinental Roman Empire, a fact that created the premises for the birth - on that

2 Nicolae Iorga, Byzance après Byzance, Bucharest, 1971; Dmitri Obolensky, The Byzantine Commonwealth, Eastern Europe 500-1453, London, 1971; I.-A. Pop, „Bisanzio dopo Bisanzio: la realtà e l'eredità imperiale nell'Europa centro-orientale", in Andrea Piras (ed.), Imperia. Esperienze imperiali nella storia d'Europa, Rimini, 2008, pp. 29-42. 
land - of a Romanic people, i.e. the Romanians. Afterwards, Germanic, Turan (Turkic and Ural-Altaic), Slavic etc. migrants passed. The Slavic people were the most numerous and the most powerful, strongly influencing the Romanian's ancestors and leading to the establishment of neighbouring Slavic states (Bulgaria, Kievian Russia, Serbia, Croatia etc.). At the threshold between the millennia, the Hungarian Finno-Ugric people and the Szeklers appeared, as well as the Germanic "guests" - generically called Saxons (Saxones) - between the $12^{\text {th }}$ and $13^{\text {th }}$ centuries. The main Transylvanian populations in the Middle Ages were the Romanians, the Hungarians, the Saxons and the Szeklers, while the main religions were Orthodoxy and Catholicism. The conquest and integration of Transylvania into the Kingdom of Hungary $\left(11^{\text {th }}-12^{\text {th }}\right.$ centuries $)$, a Catholic state, led to the full acceptance of the Transylvanian Catholic ethnic groups (Hungarians, Saxons, Szeklers) and to the marginalization of the Byzantine or Orthodox communities (mainly Romanians). Initially, their marginalization had ethnic or confessional causes, as a result of the increasing competition between Rome and Constantinople, based on their rivalry over the monopoly of new followers. At a certain point, Hungary - a Catholic state, created within the Patrimonium Sancti Petri and the family of kingdoms within the Roman-German Empire - took very seriously its mission of fighting against "the pagans, the heretics and the schismatics", inside and outside its borders. Or, Romanians were irremediably placed among the "Schismatics" and, consequently, they were meant to be converted or removed from power, banished or even eradicated. It was not possible for those radical plans to be implemented as such, but they undoubtedly led to discrimination. Despite it, the Transylvanian civilisation was built through the common efforts of all aforementioned ethnoconfessional groups.

For many specialists, modern Europe begins with the Protestant Reformation, a movement for which Transylvania was an extremely important scene. The $16^{\text {th }}$ century reformation transformed Transylvanian Catholics into Protestants: the Saxons became Lutherans (Evangelical), the Hungarians and the Szeklers became (most of them) Calvinist and Unitarian, while Catholics largely decreased in number (being mostly concentrated among the Szeklers). As such, a new "constitutional" organisation was imposed in Transylvania, by which Catholics' place in the rule of the country was taken by Protestants. The entire process bears the name of "tolerance regime", meaning that the confessions newly founded through the Reformation were accepted - as a result of some fierce litigations, carried out quite peacefully, with a minimal number of casualties - through the decisions taken by the country's assembly (Diet). Consequently, in a period of approximately three millennia, along with Catholicism (which became weak and had no fortunes, as they had passed to the new authorities), the Lutheran, Calvinist and Unitarian religions became "receptae" (official). The Romanian's eastern Christian fate was still 
not recognized, similarly to the Romanian community that did not have the right to participate in the rule of the country.

During the process of the Protestant Reformation imposition in Transylvania, some generous ideas of freedom (which announced the new age of modernity) were affirmed. The first was that of accepting diversity among the ancient Catholics. As such, one at a time, Lutheranism, Calvinism and, last but not least, Unitarianism (Anti-Trinitarianism) became recognized. At a certain point, due to the general enthusiasm and despite the obvious and quite fierce rivalry existing between the new cults, the country's Diet actually accepted the right of each community (be it rural or urban) to choose their confession $\left(16^{\text {th }}\right.$ century). This was an absolute novelty in $16^{\text {th }}$ century Europe. Furthermore, certain approaches to convert Romanians to Protestantism also began. However, the radicalism of the Reformation in Transylvania stopped there and even regressed soon after. As such, at the beginning of the tenth decade of the $16^{\text {th }}$ century, any "religious innovation" was completely stopped by the Diet. Moreover, the permissive right to freely chose one's religion at the community (parish) level was entirely eluded and even prohibited. Catholicism, although formally maintained among the official religions, had no more power, especially as a result of the seizure of its entire fortune, including the possessions owned by the bishops of Alba Iulia and Oradea. Attracting the Romanians to the Reformation was seen with much doubt by Romanians themselves, as well as by the recognized classes and confessions, who felt that their monopolyon power was being threatened. As a result, the initiative failed, the Romanians remaining faithful to their Orthodox belief, but that failure marginalized them and they still lacked the right to participate in the rule of the country. In fact, practically, in certain periods of the $16^{\text {th }}$ and $17^{\text {th }}$ centuries, both the (Romanian) Orthodox and the (Hungarian speaking) Catholics suffered from discrimination, through serious limitations to the exercise of their cults, hierarchy, church properties, access to cities etc. The main difference was that the Romanians / Orthodox were excluded from the ruling of the country, as well as from the right to citizenship, through legally binding official decisions, according to which Catholics were temporarily de facto discriminated, whereas, legally, they were "recepti", i.e. accepted. That fact was extremely important, however, as after the imposing of Austrian domination (1688-1699), the Catholics were de facto resettled in their position of de iure privileged people, while the Romanians remained in the same submissive position of inferior inhabitants.

\section{New and old ideas}

The analysis of this enormous transformation of the Transylvanian society may lead to several useful conclusions for current European construction. In this approach, enthusiasm has to make room for realism, starting from the premise that 
the world in the past should not be assessed according to contemporary values and conceptions, but to the mentalities of the era in question. Or, in $16^{\text {th }}$ century Europe, the transformations occurring in Transylvania were customary and unusual at the same time.

Naturally, a great change manifested itself as a result of the official acceptance of the confessions born from the Reformation. It was undoubtedly a regime of tolerance, of accepting thy neighbour, who was different from you. Generally, that situation was produced without the use of armed force, something that cannot be said about other regions of Europe at the time, such as the more civilised France. If one takes a closer look, however, things do not seem so spectacular anymore. In fact, the ancient Catholic elite in Transylvania, i.e. the country's privileged class, who had mostly turned to Protestantism, had to choose between blaming themselves and continuing to rule the country. The non-recognition of confessions stemming from the Reformation process would have led to their marginalization, to their exclusion from the privileges. In Transylvania, unlike France or Germany, almost all important Saxon, Hungarian and Szekler leaders became, one way or another, the followers of Protestantism. Consequently, Transylvania's leading elite recognized itself, re-officialised itself in order to maintain its powers, i.e. its privileges. Any other solution would have been illogical, unrealistic, leading to self-destruction. As a result, the much simpler recognition of reformed confessions was carried out in Transylvania also due to a self-preservation spirit, in order to maintain the ancient elite as the ruler of the country, whose power was based on medieval autonomies and customs.

The process was, nevertheless, far from being calm and that was not because of Catholicism (which had almost been annihilated in Transylvania before 1570), but rather because of the rivalries existing between the new confessions. The latter, especially Calvinism (practiced by Hungarian speakers) and Lutheranism (mostly adopted by German speakers) fiercely fought for supremacy. A serious rival in this competition - at least in the $16^{\text {th }}$ century - was Unitarianism, the most radical of European Protestant currents, defined (as a new and accepted confession) even in Transylvania, in Cluj. However, the Anti-Trinitarian belief was not new (it was founded on the teaching of Arius, a priest from Egyptian Alexandria, in the $3^{\text {rd }} 4^{\text {th }}$ centuries A.D.) and wad timidly reiterated in the 1540s, in Venice and then Poland, with the help of Giorgio Blandrata, Laelio Socinus, Faustus Socinus, Francesco Stancarus, Mathias Vehe Glirius etc. The most radical Unitarian ideas (engendering several trends, among which the Judeo-Christian one of the Sabbatarians) enjoyed initial success but then lost some of their supporters, especially among the less wealthy Hungarian-speaking communities of Cluj, Turda/Torda/Thorenburg and Arieş/Aranyos. Its advocates supported the uniqueness of God's person and nature, the inexistence of the Holy Trinity, the human nature of Jesus Christ, the falsity of sacraments (sacramenti), of the church's traditions, of the cult of the Virgin Mary and the saints etc. Denying the divinity of Jesus Christ led to 
two radical precepts or principles, clearly stated as follows: 1) He should not be worshiped (nonadoramus); 2) He should not be invoked when in need (noninvocando). Such Unitarian ideas were rejected and criticised not only by Catholics, but also by other Protestant beliefs. Still, together with the other Anti-Trinitarian teachings, they were embraced for a while by the nobility elite, but mostly by the lower Hungarian class. Between 1566 and 1570, the city of Cluj became the world centre of Anti-Trinitarianism, the place where it was founded and affirmed.

\section{Religion and nation}

Confessions born from the Reformation are not specific to certain nations and are not based on ethnicities. On the contrary, they have been officially open to all "languages" (peoples). The fact was obvious in Transylvania as well, where Lutheranism was initially spread among Saxons and then, quite rapidly, among Hungarians, and even among Szeklers, while Unitarianism was embraced by Hungarians and Szeklers etc. Similarly, Hungarians were Lutherans, Calvinists and Unitarian etc. Still, gradually, things started to change, along with the emphasis on the role of ethnicity, as the age of modernity got closer. As such, the Lutheran "religion" or the "religion of Sibiu" gradually became associated with the German inhabitants of Transylvania and came to be known as "the Saxon religion", while the Calvinist "religion" or the "religion of Cluj" was called by some "the Hungarian religion". Many Hungarian nobles abandoned Lutheranism for the very purpose of adhering to a "religion" that was specific to their nation; hence these confessions are also based on ethnical criteria. For instance, the June 1654 Diet of Turda issued a document stating that "As the superintendents ${ }^{3}$ and the priests of the Church of Cluj, or indeed the Hungarian one, and those belonging to the Church of Sibiu, or the Saxon one, have had a lot or arguments, debates, conflicts and differences of opinion on religious matters and especially with regard to the Eucharist ${ }^{4}$, in order to put an end to differences, appease the conscience of both parties and bring peace to the inhabitants of the country, it has been decided that in future both sides will be allowed to profess and practice the religion and the faith of both Sibiu and Cluj, but no priest from a royal town or from a town in the plains shall be allowed to preach the religion and the faith of the Church of Cluj and forcefully try and persuade the people". We see that in the country assembly, the Calvinist faith (with its several trends) was dubbed "Hungarian" and

3 Rulers, acting as bishops, of initial Protestant churches.

4 Sacrament through which the believers' communion is performed using bread and wine, transformed, through the power of the Holy Spirit, into the body and blood of God. Martin Luther accepted this sacrament almost in an unaltered way (along with two more of the total seven), albeit Protestants generally rejected the Eucharist or accepted a merely spiritual presence of Jesus Christ amidst them (in Calvinism).

5 Monumenta Comitialia Regni Transylvaniae, redactor Szilágyi Sándor, vol. II (1556-1576), Budapest, 1877, pp. 231-232. 
the Lutheran one "Saxon". In the same spirit, starting with the $16^{\text {th }}$ century, amid the strong affirmation of the Calvinist principate, the overlap between this religion and the Hungarian nation became even more obvious. As such, Transylvanian religions were delineated, although not very sharply, on national criteria. And since Romanians had been synonymous to Orthodoxy for a very long time, in that same spirit, since the $16^{\text {th }}$ century, the word "Wallachian" became synonymous with Orthodox (of eastern or Byzantine belief), so that saying Romanian was the same as saying Orthodox and vice-versa. Step by step, despite certain attempts at reversion, on the Transylvanian scene, Calvinism became the Hungarian religion for a long time, Lutheranism was the German (Saxon) religion, while Orthodoxy was the Romanian religion ("law"). The ethnic pride was obvious: in 1556, after the banishment of Austrians, Francisc Davis became the bishop of not only the Hungarian Lutheran Church, but also the Szeklar Church; Szeklers, however, although they lived in their own enclave, welldelineated under the linguistic and confessional aspects, felt threatened by the proHungarian trend represented by David and elected a Saxon bishop (Matthias Hebler); in 1559, at the moment of his resignation from the position of Lutheran bishop (he had become Calvinist in the meantime), the same Francis David proclaimed himself "Bishop of the Hungarian Churches"; some exegetes believe that Lutheran Hungarians ran the risk of being nationally assimilated by the Saxons, but were saved by the "Helvetic orientation" (or Calvinism), which, from the very beginning, emphasized the promotion of values and national language ${ }^{6}$. As such, the political nations of Transylvania started to be defined according to religion, language, origin, traditions and even territory. The land dominated by the Saxons, given to them by the king (therefore named Fundus Regius), was more and more often called the "Land of the Saxons", the land dominated by the Szeklers was called the "Land of the Szeklers", while the land predominantly inhabited by the Hungarian nobles (the seven comitatus) was sometimes referred to as the "Hungarian Land". Thus, in the land of Transylvania at that time, a gradual strengthening of ethnicity, set against the background of the ancient medieval elitist spirit, partially converted into a modern meaning, with the help of the ideas of communities of origin, language, territory and confession. There, as well as in other regions, confession became an important brand of national identity.

\section{The country of four (five) "religions", or the diversity of spiritual models in Transylvania}

In the $16^{\text {th }}$ and $17^{\text {th }}$ centuries, located at the point of contact between the Eastern Byzantine and the Western Latin civilizations, Transylvania provided the example of a European country that was home to a diversity of ethnic groups, religious denominations, cultures and models of civilization. During this period, the political

6 Vígh B., Disputele sinodale..., pp. 70-71. 
nations (estates) gradually turned into modern nations, in the ethnic sense of the term, and the original two denominations (Orthodox and Catholic) were joined by several new ones (Lutheran, Calvinist, Unitarian, Greek-Catholic etc.). These changes were peaceful and violent, quiet and agitated, innovative and retrograde, open to modernity but preserving much of the medieval rigidity. During the modern era, the three political nations (the Hungarian nobles, the Saxons and the Szeklers) turned into two distinct national groups: the Hungarians (who presently also include the Szeklers) and the Germans. Without having been an officially recognized medieval nation, the Romanians nevertheless turned into a modern nation, aware of its role despite the discrimination it faced. The official religion Roman-Catholic - gave birth to the four legally accepted denominations: RomanCatholic, Lutheran, Calvinist and Unitarian. The religion of the Romanians Orthodox - was denied official recognition both before and after the Protestant Reformation. A largely failed attempt at granting them global recognition occurred a bit later, involving the union with the Church of Rome and the creation of the Greek-Catholic Church (around the year 1700).

This extremely diverse landscape witnessed a constant vacillation between acceptance and exclusion, between peaceful integration (assimilation) and ethnicreligious revolt, between privileges and the absence thereof, between tolerance and intolerance. For centuries on end, that was the normal and natural state of affairs, in the sense that a "Catholic and apostolic" kingdom like Hungary had the mission and obligation to protect and favour Catholics and to take discriminatory measures against the others.

Consequently, religious tolerance has to be understood in the context set by the era, within its limits, marked by the arsenal of a medieval heritage. Under no circumstances should tolerance be mistaken for full religious freedom or for absolute equality between religions. Hence, it is easy to see the great rivalries between the new Protestant religions and the periods of domination of one or another, as well as the hegemony of Calvinism in the $17^{\text {th }}$ century. Leaving aside the constantly inferior status of the Orthodox Church, one has to notice the persecution of Catholicism and its church, especially by the Unitarians (dominant between 1567 and 1571). So powerful was the assault that the Catholic Church almost disappeared from Transylvania or was forced to manifest itself cryptically.

In conclusion, it could be stated that, in Transylvania, the Reformation quickly changed the landscape of political nations, i.e. of the leading elite of the country. It transformed the latter from Catholic into Protestant. Power was collegially exercised by the Hungarians, the Saxons and the Szeklers, who, from that moment on, were the followers of four religions: Calvinist, Lutheran, Unitarian and Catholic. The inhabitants of the different nations and confessions lived separately and together at the same time. Therefore, from the political viewpoint, a regime of three official nations and four official religions ruled in Transylvania. The Romanians - the most numerous 
inhabitants of the country - were left outside of the equation of power, deemed inhabitants of the inferior class, yet being accepted to live usque ad beneplacitum principum et regnicolarum, i.e. until the good will of the princes and (lawful) citizens lasted.

Therefore, Transylvania was a melting pot of the new modern Europe, with all its freedoms and constraints, with its acceptance and rejection, with ideas for progress and bizarre perpetuations of medieval traditions. From certain points of view, the inhabitants of the Transylvanian Country provided Europe with lessons on generosity and tolerance, which, even though not constantly and generally applied, left in public awareness an imprint of cohabitation that remains valid even at present.

\section{Appendices:}

\begin{tabular}{|c|c|}
\hline Ideas of acceptance (tolerance) & Ideas of exclusion (discrimination) \\
\hline $\begin{array}{l}\text { Official recognition of Lutheranism, Calvin- } \\
\text { ism and Unitarianism }\end{array}$ & $\begin{array}{l}\text { Drastic limitation of Catholicism (expropria- } \\
\text { tion, seizures, interdictions) }\end{array}$ \\
\hline $\begin{array}{l}\text { Recognition of the communities' right to } \\
\text { freely choose their religion }\end{array}$ & $\begin{array}{l}\text { Unfair competition between the new reli- } \\
\text { gions; pressures to attract Christians }\end{array}$ \\
\hline $\begin{array}{l}\text { The collegial participation in the exercise of } \\
\text { power }\end{array}$ & $\begin{array}{l}\text { Exclusion from the collegial power of the } \\
\text { Romanian community; the leadership of the } \\
\text { Orthodox church was forced to convert to } \\
\text { Calvinism }\end{array}$ \\
\hline Acceptance of thy different neighbour & $\begin{array}{l}\text { Retraction of the communities' right to freely } \\
\text { choose their religion }\end{array}$ \\
\hline $\begin{array}{l}\text { The increased role of teaching, education and } \\
\text { culture }\end{array}$ & Contempt for unofficial confessions \\
\hline $\begin{array}{l}\text { Prevalence of the decision of the country's } \\
\text { Diet compared to local decisions (at the level } \\
\text { of comitatus, Land of the Saxons, Land of the } \\
\text { Szeklers) }\end{array}$ & $\begin{array}{l}\text { Limitation of the right to religious } \\
\text { "innovations" }\end{array}$ \\
\hline $\begin{array}{l}\text { Emphasis on the inhabitants' mobility in } \\
\text { Europe }\end{array}$ & $\begin{array}{l}\text { Maintenance of medieval privileges and } \\
\text { autonomies }\end{array}$ \\
\hline
\end{tabular}

\begin{tabular}{|l|l|}
\hline Ideas and means of unity (integration) & $\begin{array}{l}\text { Ideas and means of dividing (separation, } \\
\text { segregation) }\end{array}$ \\
\hline The prince, the prince's council & $\begin{array}{l}\text { Division of the country into different regions, } \\
\text { based on ethnic criteria }\end{array}$ \\
\hline Diet (country's assembly) & Exaggerated power of local autonomies \\
\hline $\begin{array}{l}\text { Representation of all recognised nations in } \\
\text { the central governing bodies }\end{array}$ & $\begin{array}{l}\text { Refusal to accept Romanian representatives } \\
\text { (and other ethnicities) in the central govern- } \\
\text { ing bodies }\end{array}$ \\
\hline $\begin{array}{l}\text { Representation of all "official religions" in } \\
\text { the central governing bodies }\end{array}$ & $\begin{array}{l}\text { Refusal to accept Orthodox representatives } \\
\text { (and other religions and cults) in the central } \\
\text { governing bodies }\end{array}$ \\
\hline Single foreign policy & Connections to rival foreign powers \\
\hline
\end{tabular}

